\title{
Scalp Pink Tumors Showing Multiple Rosettes
}

\author{
Karla Patricia Estrada-Ramírez ${ }^{1}$, Denisse Herrera-Bringas² ${ }^{2}$ Maribet González-González ${ }^{3}$, \\ Daniel Alcalá-Pérez ${ }^{2}$
}

1 Department of Dermatology, Centro Dermatológico Dr. "Ladislao de la Pascua”, Mexico City, México
2 Department of Dermato-Oncology, Centro Dermatológico Dr. "Ladislao de la Pascua", Mexico City, Mexico
3 Department of Dermatopathology, Centro Dermatológico Dr. "Ladislao de la Pascua", Mexico City, México

Citation: Estrada-Ramírez KP, Herrera-Bringas D, González-González M, Alcalá-Pérez D. Scalp pink tumors showing multiple rosettes. Dermatol Pract Concept. 2022;12(1):e2022020. DOI: https://doi.org/10.5826/dpc.1201a20

Accepted: May 26, 2021; Published: January 2022

Copyright: @2022 Estrada-Ramírez et al. This is an open-access article distributed under the terms of the Creative Commons Attribution-NonCommercial License (BY-NC-4.0), https://creativecommons.org/licenses/by-nc/4.0/, which permits unrestricted noncommercial use, distribution, and reproduction in any medium, provided the original authors and source are credited.

Funding: None.

Competing interests: None.

Authorship: All authors have contributed significantly to this publication.

Corresponding author: Daniel Alcalá Pérez, MD, Department of Dermato-Oncology, Centro Dermatológico Dr. "Ladislao de la Pascua”, Mexico City, Mexico. E-mail: alcalad32@yahoo.com.mx

\section{Case Presentation}

A 46-year-old male with history of complete surgical excision of a well-differentiated cutaneous squamous cell carcinoma in the right preauricular area in 2018 visited the dermatology unit complaining of 3 growing pink nodular lesions on the scalp (Figure 1A). Dermoscopy revealed multiple rosettes with homogeneous white-pink areas (Figure 1B). Two tumors were excised with a preliminary diagnosis of basal cell carcinoma, and histopathology reported molluscum contagiosum (MC) (Figure 1C). As the presence of giant MC on the face is a clue for HIV infection, laboratory tests were performed and confirmed the suspected cause of immunosuppression.

\section{Teaching Point}

The diagnosis of MC is straightforward when typical findings are seen; however, some cases may be indistinguishable from other tumors, such as basal cell carcinoma [1]. Dermoscopy can improve the accuracy of pink tumor diagnosis, as rosettes can be observed in many tumoral skin lesions [2]. Multiple pink nodular lesions on the face or scalp with rosettes on dermoscopy should raise the suspicion for MC.

Informed consent: Informed consent for publication of clinical details and clinical images was obtained from the patient. 


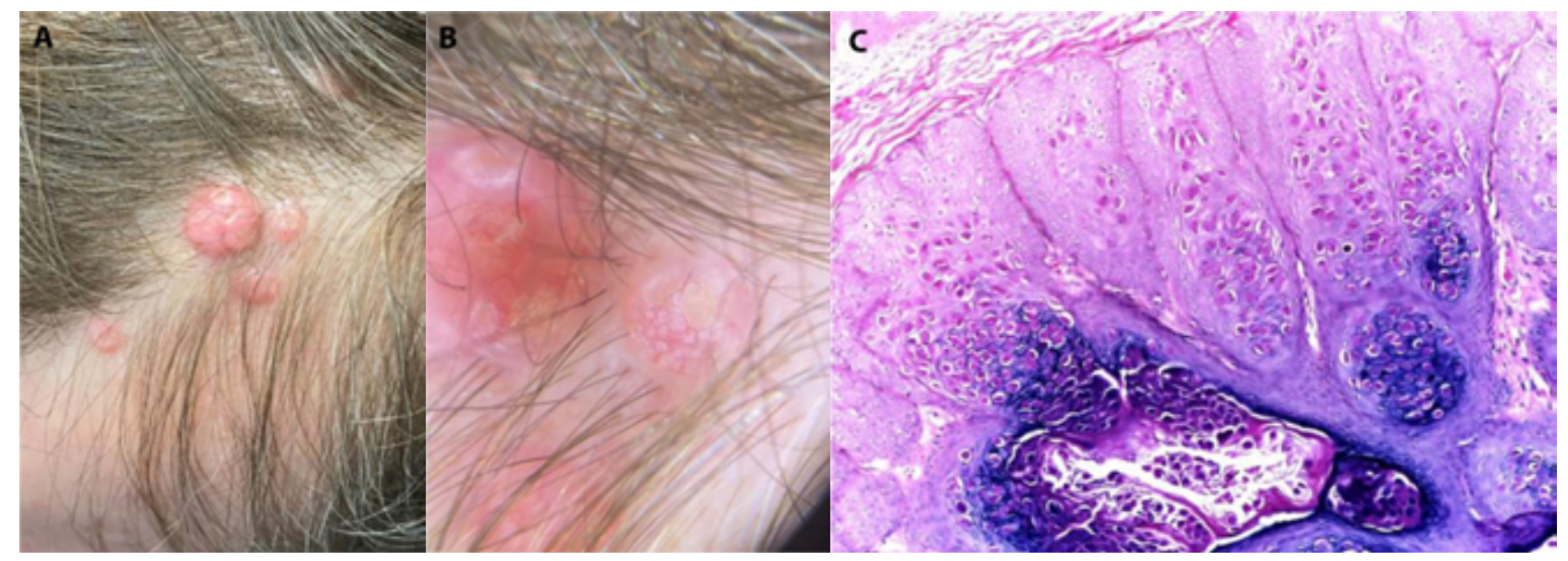

Figure 1. (A) Pink tumor on the left fronto-parietal scalp. (B) Dermoscopy demonstrated multiple rosettes. (C) Histopathology revealed epidermal lobes in the dermis containing the molluscum bodies. (H\&E, magnification $\times 10)$.

\section{References}

1. Meza-Romero R, Navarrete-Dechent C, Downey C. Molluscum contagiosum: An update and review of new perspectives in etiology, diagnosis, and treatment. Clin Cosmet Investig Dermatol. 2019;12:373-381. DOI:10.2147/CCID.S187224. PMID: 31239742. PMCID: PMC6553952.
2. Haspeslagh M, Noë M, De Wispelaere I, et al. Rosettes and other white shiny structures in polarized dermoscopy: Histological correlate and optical explanation. J Eur Acad Dermatology Venereol. 2016;30(2):311-313. DOI:10.1111/jdv.13080. PMID: 25786770. 